Sofia Pinchuk, Svetlana Gubenko and Elena Belaya

\title{
CORRELATION BETWEEN ELECTROCHEMICAL CORROSION AND STRUCTURAL STATE OF STEEL BY SIMULATION OF OPERATION CONDITIONS OF RAILWAY WHEELS
}

\author{
National M etallurgical Academy of Ukraine, 4, Gagarin ave., \\ Dnepropetrovsk-5, 49600, Ukraine \\ belaya_alena @mail.ru
}

Received: N ovember 11, 2009

(C) Pinchuk S., Gubenko S., Belaya E., 2010

\begin{abstract}
Corrosion mechanism and corrosion rate of wheel steel of different chemical and structural compositions have been investigated. It has been shown that "white layers", variation in grains size and structure streakiness of wheel steel increase corrosion rate. Wheel steel with vanadium additives corrodes more quickly than that without vanadium. Non-metallic inclusions are the centers of corrosion nucleation and their influence on corrosion depends on inclusion type. Corrosion mechanism of wheel steel has been discussed.
\end{abstract}

Keywords: corrosion, wheel steel, steel structure, "white layers".

\section{Introduction}

Chemical technologies as well as any technologies based on laws of physics, chemistry, mechanics, biology, and other natural sciences are created to satisfy utilitarian needs of the society. An important criterion of technology perfection level is the quality of satisfaction of the mentioned needs which is realized by quality of technology functioning results, which in turn, is the quality of products or services rendered for the society. The product's quality is formed at the stages of technology creation and implementation but it is realized during operation under concrete conditions.

Transport and transport services are one of the most important necessities of modern civilization. At present railway transport occupies the leading place in the system of satisfaction of these requirements. Railway wheels are one of important elements of rolling stock. The problem of growth of railway wheels reliability and service life is connected with the development of modern technologies at all stages of their production (steel melting and production of steel billet, wheels forming under pressure, heat treatment); development of new advanced chemical compositions of wheel steels with phase and structural state necessary for assurance of high mechanical and operation properties; as well as with the development of new constructions of wheels for their operation under different conditions.

Operation conditions of railway wheels are differed by loads acting on the wheel and ensuring different character of its stressed state, influence of environment (chemical composition, temperature, pollutions), and by quality of service. Nonobservance of the proper level of operation conditions may cause wheels damage. The efforts of metallurgists, metal scientists, mechanics, and operating staff must be directed to solving of the important problem of assuring high level of railway wheels reliability and service life.

Exploitation and transportation of railway wheels are realized without effective anticorrosion protection. The increased influence of environment aggressive factors in large industrial centers creates an urgent problem of wheels corrosion damage prevention.

Railway wheels are exposed to corrosion during operation. Corrosion damage of steel promotes embrittlement of wheels. Corrosion of different parts of railway wheel takes place under dynamic and static conditions (atmospheric, wet, gaseous, sea-water, stress, fretting, and stray-current corrosion). The aim of this work is the comparative investigation of corrosion rate of wheel steel with different structures of different wheel elements after hot deformation, heat treatment and operation.

\section{Experimental}

Microstructural researches of wheel after operation were carried out. Structural changes near tread were studied in worn wheel 1 . The corrosion zones in different parts of wheel 1 and non-operated wheel 3 were studied. Specimens for corrosion tests were selected from different parts of tread, rim and disk of wheels 1 and 2 after operation (5 years) as well as of non-operated wheels 3 and 4 . Chemical composition of wheels steel is given in Table 1. 
Chemical composition of wheels steel

\begin{tabular}{|c|c|c|c|c|c|c|c|c|c|}
\hline \multirow{2}{*}{$\begin{array}{c}\text { Wheel's } \\
\text { number }\end{array}$} & \multicolumn{10}{|c|}{ Content of elements, \% } \\
\cline { 2 - 11 } & $\mathrm{C}$ & $\mathrm{Mn}$ & $\mathrm{Si}$ & $\mathrm{S}$ & $\mathrm{P}$ & $\mathrm{Cr}$ & $\mathrm{Ni}$ & $\mathrm{Cu}$ & $\mathrm{V}$ \\
\hline 1 & 0.59 & 0.72 & 0.34 & 0.025 & 0.012 & 0.14 & 0.15 & 0.20 & - \\
\hline 2 & 0.65 & 0.79 & 0.36 & 0.027 & 0.010 & 0.13 & 0.18 & 0.18 & - \\
\hline 3 & 0.61 & 0.78 & 0.30 & 0.029 & 0.024 & 0.17 & 0.15 & 0.16 & - \\
\hline 4 & 0.46 & 1.04 & 0.47 & 0.024 & 0.018 & 0.09 & 0.11 & 0.18 & 0.10 \\
\hline
\end{tabular}

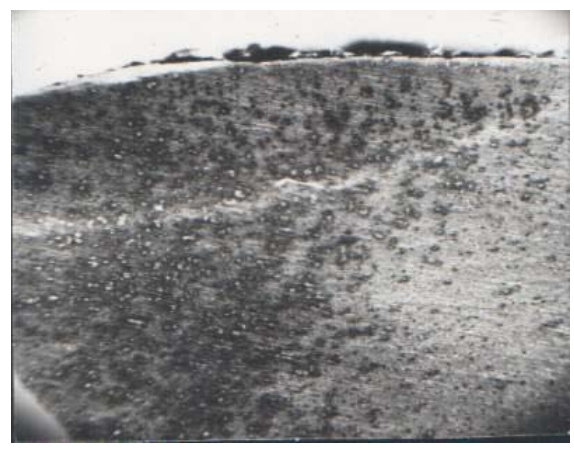

a

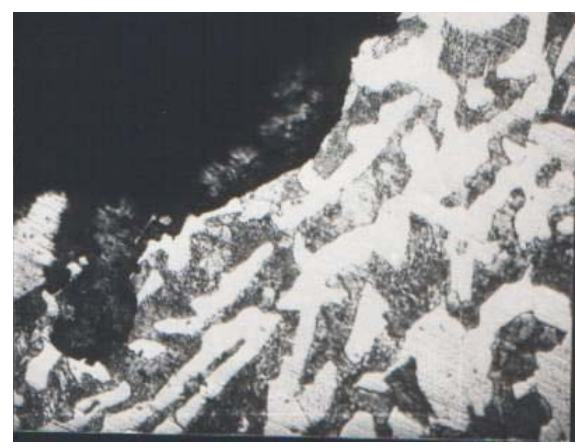

d

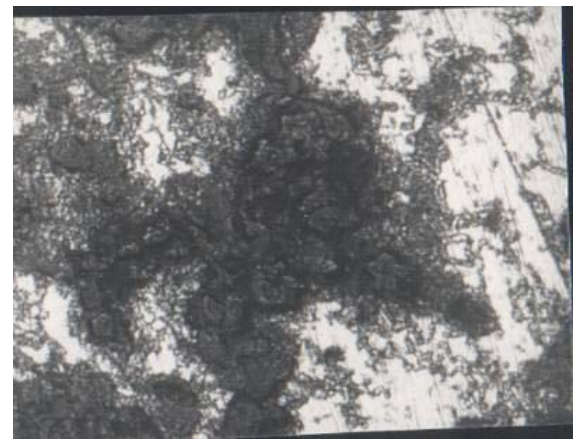

b

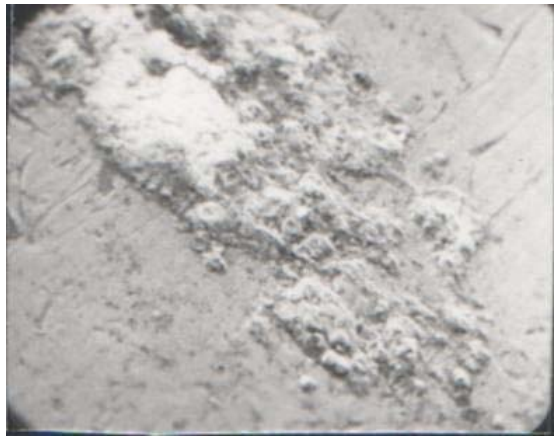

c

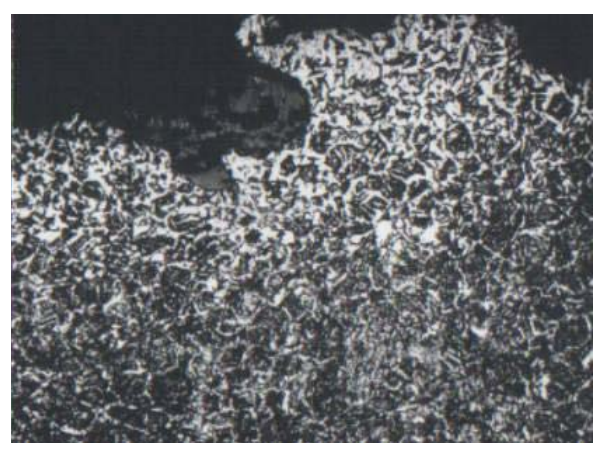

e

Fig. 1. Sections of corrosion in railway wheels 1 and 3: macro (a), x500 (b-d) and x200 (e)

Accelerated corrosion tests were carried out in a special camera with moist atmosphere containing $10 \mathrm{mg} /$ $\mathrm{m}^{3}$ of $\mathrm{SO}_{2}, \mathrm{NO}$ and $\mathrm{NO}_{2}$ at temperature of $273-278 \mathrm{~K}$ for 25 days. Such conditions best coincide with the action of industrial atmosphere [1], however, under other operation conditions there may be aggressive effect of humidity, salt, sea water, etc. Before corrosion tests the specimens were weighed and all their facets except one were covered with paraffin.

The microstructure of wheel steel corrosion zones before and after railway wheels operation was investigated using "Neohpot-21" optical microscope and JSM-35 scanning microscope.

\section{Results and Discussion}

Examination of wheels 1 and 2 after operation shows that many parts of their surface are covered by rust.
Oxidation of steel takes place at all parts of wheel - tread, disk, and hub. Oxides particles are determined by metallographic research (Figs. 1a-d). Oxidation of steel starts from the surface and penetrates into inner layers at a considerable depth. Thus long operation of railway wheels allows to see the sufficiently large sections of corrosion. Investigation of non-operated wheel 3 allows to see small sections of corrosion in wheel's different parts (Fig. 1e). These zones are ready centers of corrosion damage during operation of railway wheels.

It should be of interest to research the role of corrosion processes in the development of structural changes near tread during operation of railway wheels. Macrostructural analysis of wheel 1 with strongly worn tread shows fatigue-corrosion wear accompanied with the tread profile shape distortion. A lot of cracks from the slider to the wheel depth and steel corrosion are evident. 


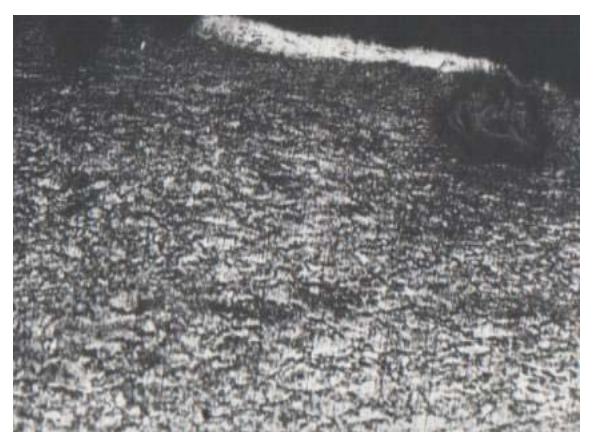

a

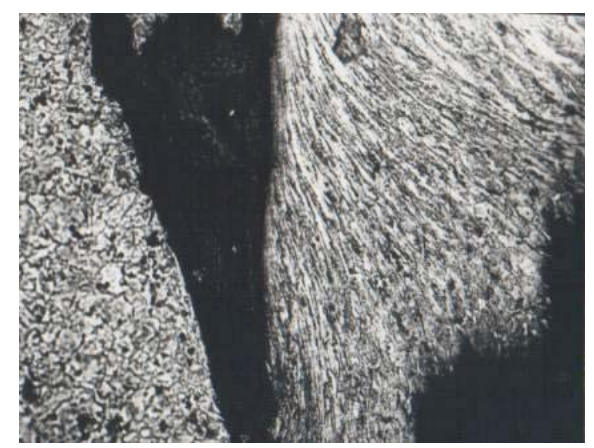

d

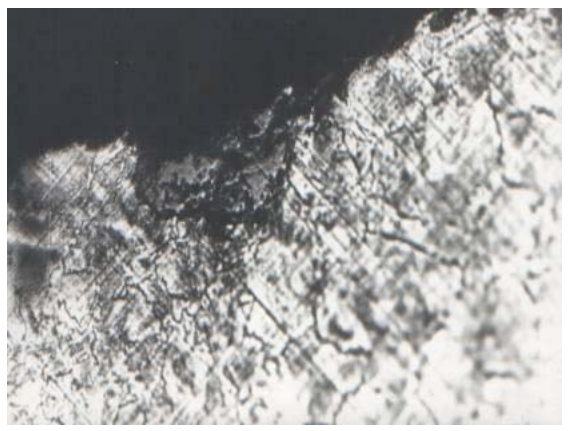

$\mathrm{b}$

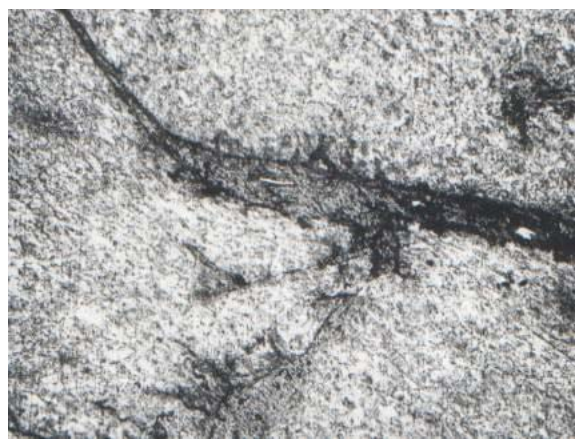

e

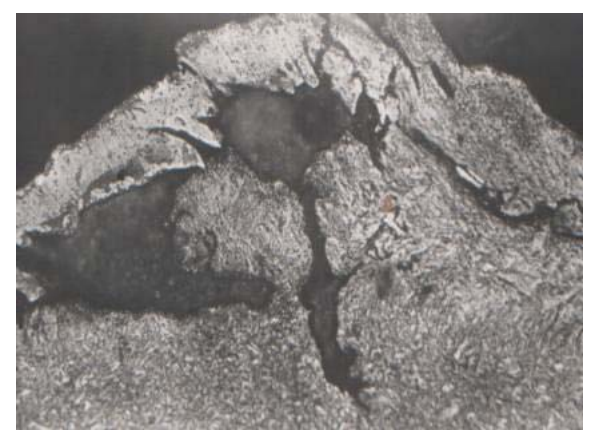

C

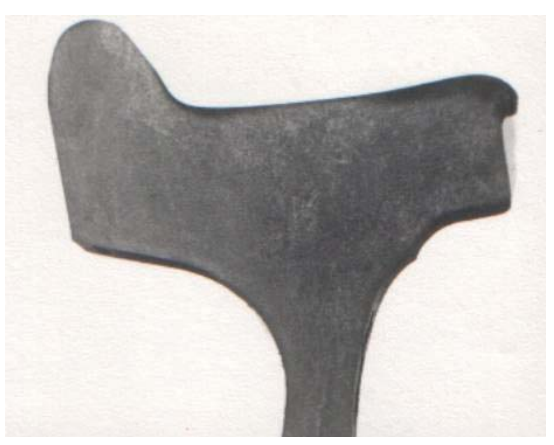

Fig. 2. Sections of corrosion near tread of railway wheel 1 after operation: x500

The microstructure of wheel rim near tread is characterized by the presence of deformed grains zone and sections of "white layer" (Fig. 2) [2]. The depth of the "white layer" is $20-40 \mathrm{mcm}$; it has intermittent character owing to the crumbling during railway wheel operation. In cavetto zone of wheel 1 the steel grains are considerably elongated and grinded (Fig. 2a), but at the egress to tread the grains are bigger, degree of their elongation decreases and they have the least value in the middle of tread (Fig. $2 b$ ). While moving from the middle of tread to the rim border the degree of grain elongation increases again. The character of steel structure in this part of tread indicates the considerable flow of steel resulting in the change of railway wheel profile [2]. In roll zone there are breakings oriented in parallel to tread. One can see from Fig. 2c that cracks spread from these breakings. As a rule cracks are on the boundary between areas with different microstructure of steel and divide zones of elongated and equiaxed grains. The roll takes place gradually, by layers, which are distorted during their shifting. At the same time brittle cracks promoting metal fracture in the layers appear. At the edge of roll the lobes with strong deformed structure (Fig. 2d) overhang on the rim side. They also indicate a lamellar mechanism of metal roll. Cracks are obvious between mentioned layers and between rolled metal and rim side. Turbulent flow of metal layers in roll zone is discovered during investigations of steel structure in the plane parallel to tread (Fig. 2e).
Zone of plastic deformation is heterogeneous by its depth and degree of grains elongation. In cavetto zone a degree of deformation $\varepsilon$ is $65-75 \%$, and then it decreases to $22-25 \%$ at the middle of tread and considerably increases to $90 \%$ in the roll zone. Appearance of deformed grains zone is connected with bearing strain of metal in the contact with rail. Plastic shears in the thin surface layer take place under relatively high pressure and cyclically changeable temperature. The character of steel microstructure indicates the heterogeneous plastic deformation along rim section connected with heterogeneous distribution of contact stresses: it is known that they are higher in cavetto zone than those in the middle of tread $[2,3]$.

Analyses of metallographic investigations allows to assert that structural changes occurred near tread of railway wheel are accompanied by corrosion. Zones of corrosion damage are detected along rim section in areas with strongly deformed structure as well as in the "white layer" areas (Fig. 2a). At the roll formation on the rim side, when thin layers of steel transfer from the middle of tread to the rim border and overlap, the areas with oxidated surface of steel are in internal parts of rim (Fig. 2c and 2d) and between layers of deformed metal (Fig. 2e). Evidently, the presence of large oxide particles results not only in local fractures of tread but also in heterogeneous development of structural changes in thin layer of metal.

Structural changes near tread determine different behaviour of wheel steel during corrosion tests. Specimens 


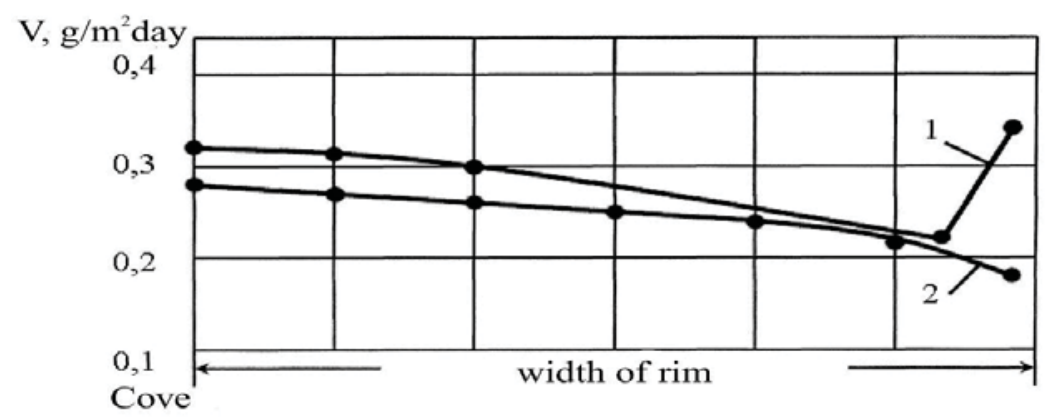

Fig. 3. Change of corrosion rate $V$ of wheel steel specimens from tread along rim width of wheels 1 and 2

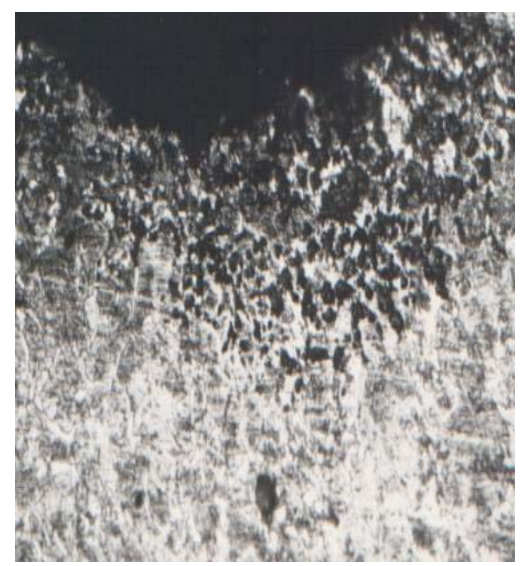

a

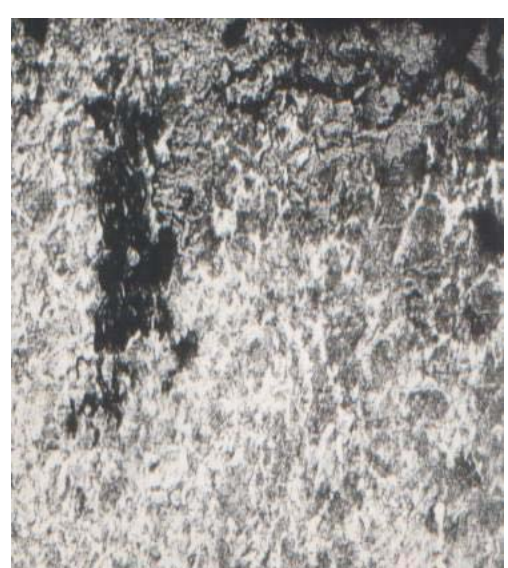

$\mathrm{b}$

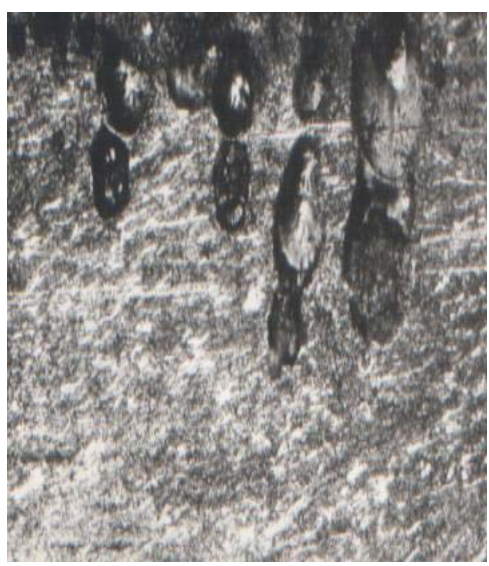

c

Fig. 4. Microstructure of wheel steel (wheel 1) after corrosion tests in different parts of tread along rim width: x200
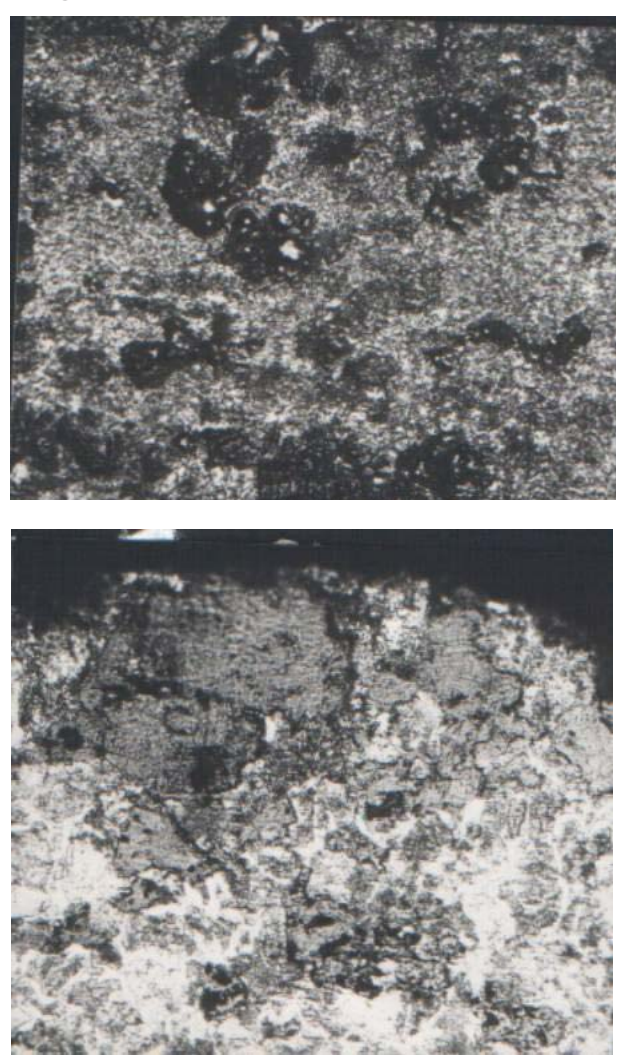

a

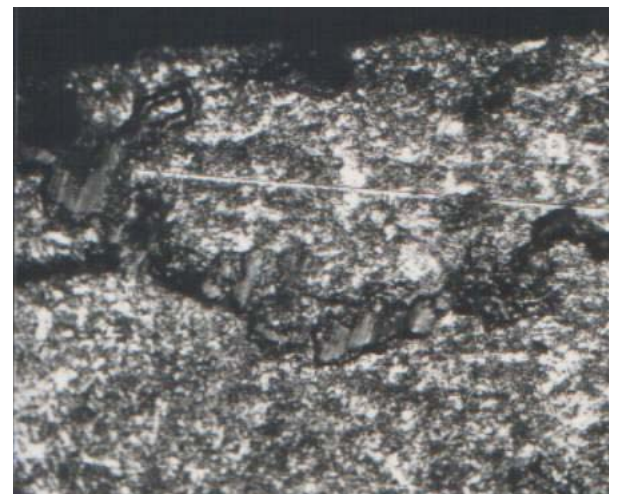

$\mathrm{b}$

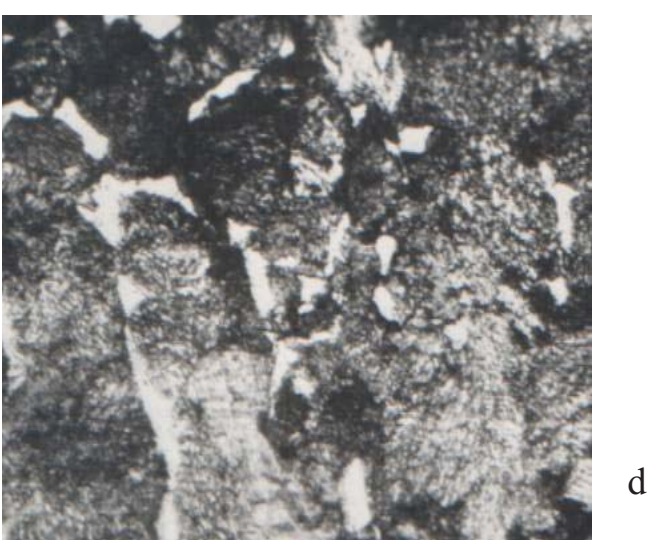

Fig. 5. Microstructure of wheel steel (wheel 2) after corrosion tests in different parts of tread along rim width: $\mathrm{x} 400$ 
from worn wheels 1 and 2 were tested for corrosion. Specimens from wheels 1 corrode with different rate which decreases from cavetto zone along rim width and increases only near the end of tread in the roll zone (Fig. 3, curve 1). Thin parts of "white layer" corrode very quickly and are not detected in the steel structure.

The change of corrosion rate and mechanism is obviously connected with the change of plastic shear zone character. In the cavetto zone where grains are elongated the corrosion rate is maximum. A lot of small $(<20 \mathrm{mcm})$ oval localized centers of hot-spot corrosion are detected (Fig. 4a), which penetrate to considerable depth. Maximum corrosion rate in the cavetto zone is explained by the influence of plastic deformation creating stresses in metal. In the middle of tread the corrosion character varies (Fig. 4b). Corrosion friable film with microcracks is formed over specimen surface. Corrosion rate of specimens from the middle of tread toward side of rim decreases to the minimum and increases only in the roll zone (Fig. 3, curve 1). Hot-spot corrosion appears again (Fig. 4c). Average size of corrosion centers is $0.6 \mathrm{~mm}$. Increase of corrosion rate in the roll zone is explained by the influence of considerable plastic deformation and also by the presence of cracks between layers of rolled metal. Corrosion centers in the roll zone are considerably larger than in the cavetto zone. Thus heterogeneous plastic deformation along rim width, which takes place during operation of railway wheels, promotes the heterogeneous corrosion fracture of tread.

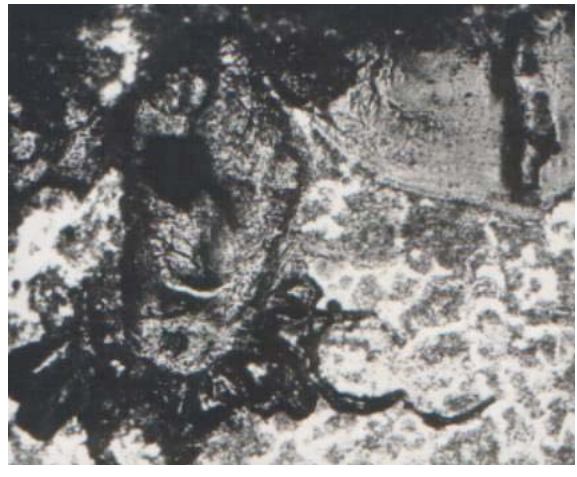

a

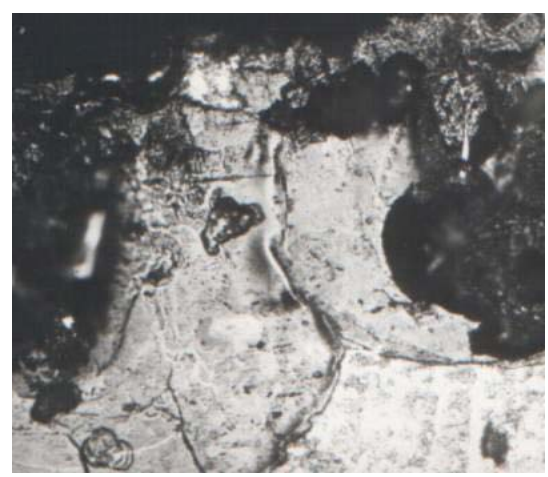

b

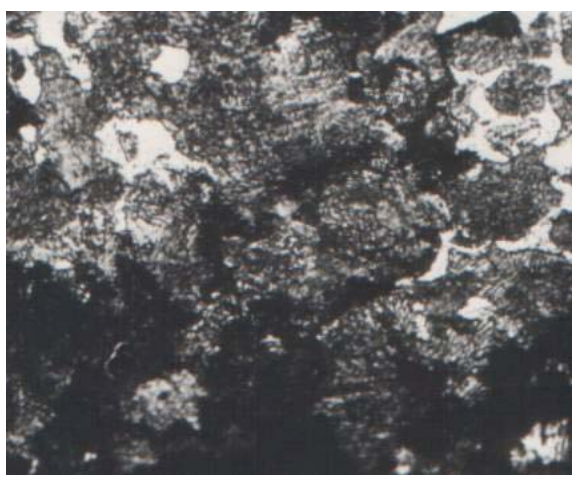

c

Fig. 6. Microstructure of specimens from the central part of rims of wheel 1 (a) and 2 (b) and from disk of wheel 2 (c): $\mathrm{x} 400(\mathrm{a}-\mathrm{c})$ and $\mathrm{x} 200(\mathrm{~d})$

Table 2

Results of corrosion tests of wheel steels

\begin{tabular}{|c|c|c|c|c|c|}
\hline \multirow{2}{*}{$\begin{array}{l}\text { Wheel } \\
\text { number }\end{array}$} & \multirow[b]{2}{*}{ Place of specimens selection } & \multirow[b]{2}{*}{ Microstructure of wheel steel } & \multicolumn{2}{|c|}{ Corrosion index } & \multirow[b]{2}{*}{$\begin{array}{c}h, \\
\mathrm{mcm}\end{array}$} \\
\hline & & & $K_{1}, \mathrm{~g} / \mathrm{cm}^{2}$ & $K_{2}, \mathrm{~g} / \mathrm{m}^{2} \cdot \mathrm{h}$ & \\
\hline 1 & \multirow[t]{2}{*}{ middle of tread after operation } & $\begin{array}{c}\text { elongated grains of ferrite and } \\
\text { pearlite }\end{array}$ & 24.058 & 0.408 & 222 \\
\hline 2 & & "white layer" & 22.9643 & 0.359 & 204 \\
\hline 1 & \multirow{2}{*}{$\begin{array}{l}\text { centre part of rim after } \\
\text { operation }\end{array}$} & $\begin{array}{c}\text { equiaxed grains of ferrite and } \\
\text { pearlite }\end{array}$ & 13.30 & 0.225 & 140 \\
\hline 2 & & $\begin{array}{c}\text { equiaxed grains of ferrite and } \\
\text { pearlite }\end{array}$ & 17.0642 & 0.289 & 125 \\
\hline 1 & \multirow{2}{*}{ disk after operation } & ferrite and pearlite, banding & 21.7702 & 0.389 & 166 \\
\hline 2 & & ferrite and pearlite, no banding & 22.8889 & 0.368 & 159 \\
\hline 4 & tread after heat treatment & sorbite of tempering & 17.8182 & 0.302 & 148 \\
\hline 4 & $\begin{array}{c}\text { centre part of rim after heat } \\
\text { treatment }\end{array}$ & ferrite and pearlite & 18.8102 & 0.319 & 167 \\
\hline 3 & tread after heat treatment & sorbite of tempering & 19.6316 & 0.327 & 115 \\
\hline 3 & $\begin{array}{c}\text { centre part of rim after heat } \\
\text { treatment }\end{array}$ & ferrite and pearlite & 24.069 & 0.401 & 138 \\
\hline
\end{tabular}


Specimens from worn wheel 2 also corrode with different rate, which monotonically decreases from the cavetto zone along rim width (Fig. 3, curve 2). "White layer" corrodes via pitting corrosion practically to the all depth (Fig. 5a). In the areas with primary structure of steel (pearlite + ferrite) and small zones of "white layer" the corrosion begins on the surface centers of attack and penetrates deep into steel as cracks (Fig. 5d) or as compact front (Fig 5c). Microcracks penetrate from the corrosion areas, mainly along the boundaries of ferrite-pearlite and pearlite, which has well-developed interphase ferritecementite boundaries (Fig. 5d).

Corrosion of specimens from the central part of rims of wheels 1 and 2 takes place via formation of steel large oxidated centers (Figs. 6a and 6b). Corrosion centers are formed on the specimens surface and then penetrate into the depth of specimens widening till they contact with each other. At the same time structural and phase stresses originate in oxides and on the oxide-steel boundaries resulting in microcracks appearance. Sizes of corrosion centers in this case are sufficiently great (1-2 $\mathrm{mm})$. Corrosion rate of metal rim having ferrite-pearlite structure for wheels 1 and 2 is approximately the same but higher than that of steel from tread (Table 2).

Metal of wheel disk corrodes more quickly than metal of rim central part (Table 2). Corrosion process spreads mainly along pearlite areas (Fig. 6c), as well as along ferrite-pearlite boundaries. Corrosion mechanism for rim and disk metals is different: large corrosion centers are present in the rim inside areas and a lot of small corrosion centers are situated in the surface layer of the disc. From corrosion centers intercrystalline cracks spread along pearlite and ferrite-pearlite boundaries. Corrosion rate of specimens from disk of wheel 1 is slightly higher than that of wheel 2.

Corrosion of specimens from tread of heat treated wheels 3 and 4 (with addition of vanadium), having secondary sorbite structure, has lamellar or film character. Specimens from rim central part of wheels 3 and 4 have the same character of corrosion (Figs. 7a and 7b). Brittle cracks spread from friable oxides to steel. Steel with vanadium additives corrodes more quickly than ordinary wheel steel (Table 2). It is known that vanadium as well as manganese [1] promotes the decrease of steel corrosion resistance. The tread after heat treatment corrodes more quickly than tread after operation. Corrosion of specimens from the rim central part of wheels 3 and 4 has pitting character with cracks distributed along pearlite.

It should be noted that steel with martensite structure has the lowest corrosion resistance [1]. During heat treatment in martensite structure considerable stresses are formed which decrease corrosion resistance of steel. Moreover, martensite structure decreases the brittle fracture resistance of steel. Hence, martensite structure is inadmissible for railway wheels.
Investigation of corrosion products structure shows the heterogeneous structure of powder. White powder hydrate $\mathrm{Fe}(\mathrm{OH})_{2}$ is an upper layer and red rust containing $\mathrm{Fe}_{\text {com }}(48.25 \%), \mathrm{Mn}(0.37 \%)$ and $\mathrm{C}(2.87 \%)$ is the bottom layer.

Different corrosion rate of wheel steel is explained by its different structural state. In worn-out railway wheels tread corrodes more quickly than metal from the rim central part. It is explained by the influence of stresses created by plastic deformation in thin surface layer. Areas of "white layer" over tread surface favor retardation of corrosion. Such effect may be explained by superdispersed structure of "white layer" [2, 3]. Metal of disk corrodes more quickly than metal from the rim central part due to the coarser ferrite-pearlite structure of disk and presence of ferrite banding of steel structure.

In heat treated railway wheels tread corrodes more slowly than metal from the rim central part. It is connected with more dispersed ferrite-pearlite structure of tread after heat treatment. Microaddition of vanadium accelerates corrosion of tread and rim central part.

Regularities of wheel steel structure influence on the corrosion rate are confirmed also by the results of definition of corrosion penetration depth $h$ from surface to specimens having different microstructure (Table 2). Average value $h$ is determined by metallographic method measuring the average depth of all investigated corrosion zones. It is necessary to take into consideration that values $h$ given in Table 2 are measured for the middle part of tread after operation of wheels 1 and 2 . However in cavetto zone of wheel 1 value $h$ is $342 \mathrm{mcm}$, in the roll zone about $600 \mathrm{mcm}$.

Thus, the more dispersed the structure of the wheel steel, the smaller the corrosion rate. Coarse-graininess, variation in grain size, and banding of wheel steel structure increase the corrosion rate.

Research of corrosion areas in railway wheels after operation and heat treatment before operation has shown the great influence of non-metallic inclusions on corrosion process. Electro-chemical heterogeneity of railway wheel surface is one of the main factors defining corrosion behavior of wheel steel. The presence of non-metallic inclusions differing from steel matrix by physical-chemical properties results in the appearance of corrosion microcells and reinforcement of electro-chemical heterogeneity of railway wheel surface. Oxides $\mathrm{Al}_{2} \mathrm{O}_{3}, \mathrm{MnO} \cdot \mathrm{Al}_{2} \mathrm{O}_{3},(\mathrm{Fe}$, $\mathrm{Mn}) \mathrm{O}$, sulphides (Fe, Mn)S, silicates $\mathrm{SiO}_{2}, \mathrm{MnO} \mathrm{SiO}_{2}$, $\mathrm{FeO} \mathrm{SiO}_{2}$, and carbonitrides $\mathrm{TiCN}$ are present in wheel steel. All these non-metallic inclusions are cathodes with respect to metal matrix and they are arranged in decreasing order according to electrode potential difference of wheel steel surface near non-metallic inclusions: sulphides, corundum, silica, and titanium nitride. Increasing series of non-metallic inclusions according to electrical resistivity is the same. 


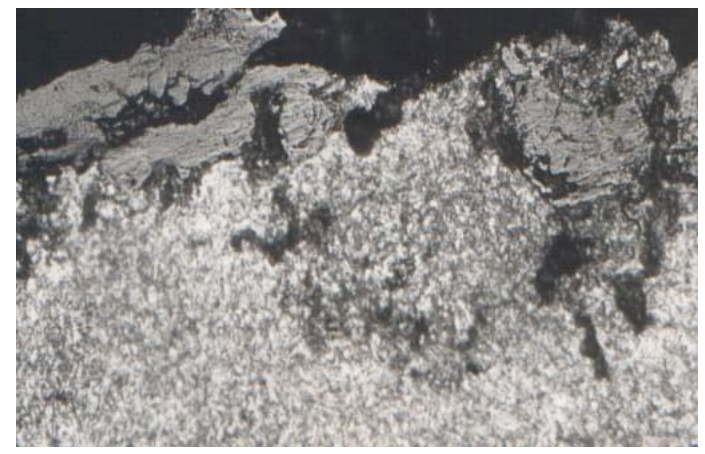

a

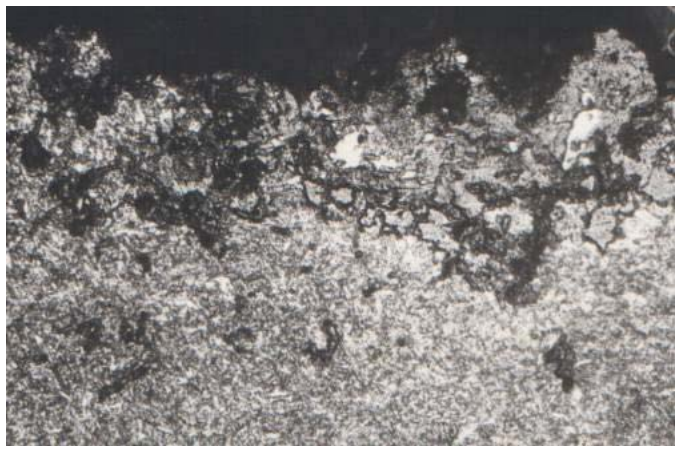

b

Fig. 7. Surface microstructure of specimens for wheel steel with vanadium additives (a) and ordinary wheel steel (b) after corrosion tests: $\mathrm{x} 200$

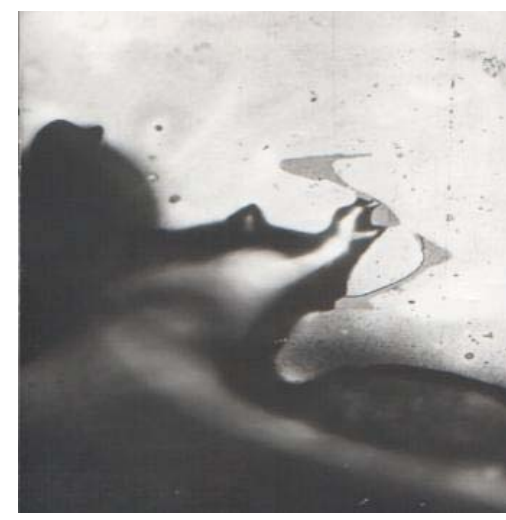

a

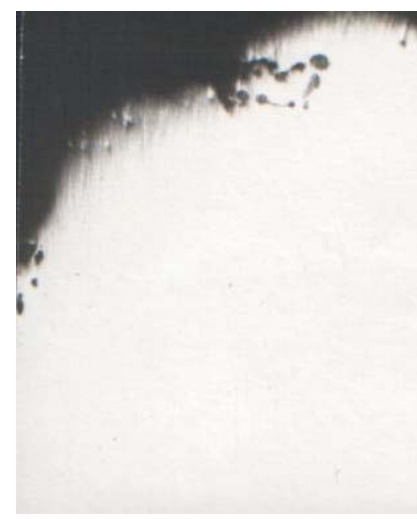

$\mathrm{b}$

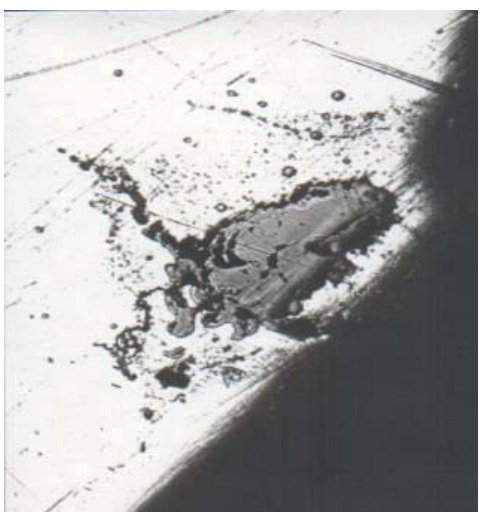

C

Fig. 8. Corrosion fracture of wheel steel near non-metallic inclusions: sulphide (Fe, Mn)S, tread of wheel 1(a); sulphide (Fe, Mn)S, rim of wheel 2 (b) and oxide $\mathrm{MnO} \cdot \mathrm{Al}_{2} \mathrm{O}_{3}$, tread of wheel 1 (c); x600

It is known that considerable thermal and deformational stresses caused by different physicalmechanical properties of non-metallic inclusions and steel matrix appear near these particles [4]. Stresses occur at the different stages of railway wheels production. Concentration of stresses promotes the corrosion damage for all kinds of non-metallic inclusions. Especially it is obvious for external stresses. In our researches the nucleation and localization of corrosion fracture of wheel steel are observed near different kinds of non-metallic inclusions in both worn and heat treated railway wheels (Fig. 8).

Thus, a metallurgical factor, namely contamination of wheel steel by non-metallic inclusions, is a very important factor in the problem of corrosion fracture of railway wheels.

Corrosion is very dangerous for reliability and service life of railway wheels. It is known by the tests in air that time necessary for fatigue crack nucleation over initial surface of metal can foot up to $90 \%$ of total service life of metal wares but corrosion shortens this time to $10 \%$ [5]. Chemical energy released as the result of corrosion can reduce effective surface energy necessary for crack nucleation. Wear-resistance of tread depends on surface condition. Formation of oxides on the tread surface due to corrosion changes properties of this surface (strength, plasticity, and wear-resistance) and affects the condition of interaction between railway wheel and rail during operation.

\section{Conclusions}

Corrosion of railway wheels during operation decreases their reliability and service life. Corrosion mechanism and corrosion rate depend on chemical composition and structure of wheel steel. Non-metallic inclusions affect the corrosion damage of railway wheels in a great degree. It is necessary to work out anticorrosion measures during all stages of wheel production, storage, transportation, and operation.

\section{References}

[1] Azchogin F.: Korrozionnoe Razrushenie I Zashchita Stali. Metallurgiya, Moskwa 1974.

[2] Taran Yu., Esaulov V. and Gubenko S.: Metallurg. i Gornodobyvaushaya Prom., 2000, 2, 42.

[3] Taran Yu., Esaulov V. and Gubenko S.: Chernaya Metallurg., 1989, 9, 101.

[4] Gubenko S.: Preobrazovanie Nemetallicheskih Vklucheniy v Stali. Metallurgiya, Moskwa 1991.

[5] Ryabchenkov A. and Nikiforova V.: Metallovedenie i Termoobrabotka, 1956, 8, 9. 


\section{ЗАЛЕЖНІСТЬ ЕЛЕКТРОХІМІЧНОЇ КОРОЗІЇ ВІД СТРУКТУРНОГО СТАНУ СТАЛІ ПРИ МОДЕЛЮВАННІ УМОВ ЕКСПЛУАТАЦЇ̈ ЗАЛІЗНИЧНИХКОЛІС}

Анотація. Вивчено механізм та швидкість корозіі колісноӥ сталі з різним хімічним складом і структурним станом. Показано, щзо "білі шари", різнозернистість та смугастість структури колісної сталі збільшують ивидкість корозії. Досліджено мікроструктуру сталі із різних елементів коліс після експлуатації. Встановлено, що колісна сталь 3 додаванням ванадію кородує швидше у порівнянні зі сталлю, що не містить ванадію. Неметалеві включення є иентрами зародження корозії, їх вплив на ї̈ розвиток залежить від типу включень. Запропонований механізм корозії колісної сталі.

Ключові слова: корозія, колісна сталь, структура сталі, "білі шари”. 